\title{
Insilico Analysis of PHB from Halophiles for potential Bio- medical applications
}

\author{
Vinod .P.S ${ }^{1}$, Neha Guttikonda ${ }^{2}$, Snehal.M.Mathe ${ }^{2}$ and M B Sulochana ${ }^{1}$ \\ ${ }^{1}$ Department of Biotechnology, Gulbarga University, Kalaburagi, Karnataka, India \\ ${ }^{2}$ Walchand center for biotechnology Solapur, Solapur University, Solapur, Maharashtra, India
}

\begin{abstract}
Polyhydroxybutyrate (PHB) is an important biopolymer accumulated by halophilic organisms. PHA is a family of polyesters is accumulated as granules in the cell of bacteria. Polyhydroxybutyrate (PHB) can be used as an alternative polymer to polylactide-glycolides for drug carrier production. It is a linear homopolymer biosynthesized by various strains of bacteria by condensation of D (-)-B-hydroxybutyric acid and used as an energy and carbon source. PHB can be obtained by extraction from bacteria or by chemical synthesis. To be suitable as drug carrier the PHB (polymer) has to be biocompatible, biodegradable in certain applications, and nontoxic. PHB seems to be biocompatible and biodegrades readily to carbon dioxide in bacteria; however, in humans, the reports are few and contradictory. The PHB was extracted from halophilic bacteria. The structural characterization of PHB was done by using NMR (nuclear magnetic resonance). To genenerate SMILES the structure were drawn in MarvinSketch. The PHB were screened based on the Lipinski's rule of 5. The PHB molecule was subjected to the toxicity analysis and those that passed the toxicity test analyzed for docking studies.
\end{abstract} Keywords : PHB, Nuclear magnetic resonance (NMR), MarvinSketch, Insilico.

\section{INTRODUCTION}

Polyhydroxybutyrate (PHB) is an important biopolymer accumulated by halophilic organisms. PHA production by halophilic microorganisms has attracted much attention in recent years. PHBs are a type of PHA. Artificial polymers cause serious environmental issues because of their nonbiodegradability. In order to reduce the amount of plastic waste, world-wide programs for efficient management of utilized plastic materials, such as recycling, have been started. Another solution to reduce plastic residues is the use of biodegradable plastics [1]. Polyhydroxyalkaonates (PHAs) are polyesters accumulated by different bacteria's under uneven growth conditions, when the carbon substrate is in excess and other nutrients such as nitrogen, sulfur, phosphorus or oxygen are in lacking [2]. Polyhydroxybutyrate (PHB) is intracellular carbon storage mechanisms for many species of halophilic microorganism. PHA is made by different microorganisms and can easily be broken down by them. Many studies have shown that PHA is readily degraded by a variety of microorganisms when placed in a natural ecosystem, such as the soil or aqueous environments [3].

PHA varities exhibit thermal and mechanical properties that are similar to petroleum-based plastics, such as polypropylene [4]. PHA materials must also not trigger immune responses during degradation in the body to be considered biocompatible. Typically, 
PHA polymers are reducing by the action of nonspecific lipases and esterase's in nature [5]. Bacterial PHAs could be divided into two groups depending on the number of carbon atoms in themonomeric units: short-chain-length (SCL) PHB, which consist of 3-5 carbon atoms, and medium-chain-length (MCL) PHB, which consist of 6-14 carbon atoms [6].The use of poly (3-hydroxybutyrate) (PHB) as carriers for drug delivery or scaffolds in tissue engineering.PHB have many advantages when compared to other chemically produced polymers like polyglycolate, polylactate, and poly(lactide-co-glycolide) which include excellent biocompatibility, biodegradability, easier processibility, and the controllable retarding properties which can be modulated by alternative in processing and molecular weight of the polymer composition. PHB in combination with other biocompatible and nontoxic polymers would also have an enhanced scope in biomedical applications [7].

\section{METHODS AND MATERIAL}

\section{Insilico analysis of PHB}

\section{A) Thermal and mechanical properties:}

Matweb tool predicts mechanical \& thermal properties. Matweb tool supports for calculation of important properties Melting Temperature $\left(\mathrm{Tm},{ }^{\circ} \mathrm{C}\right)$, Tensile Strength (Mpa), Tensile modulus (GPa), Elongation at break (\%), Glass transition temperature $\left(\mathrm{Tg},{ }^{\circ} \mathrm{C}\right)$.

\section{B) Virtual screening by Lipinski Rule of Five:}

Molecular descriptors and drug likeliness properties of compounds were analyzed using the Molinspiration server with based on Lipinski's Rules. Molinspiration server supports for calculation of important molecular properties such as $\log \mathrm{P}$, polar surface area, number of hydrogen bond donors and acceptors, as well as prediction of bioactivity score for the most important drug targets GPCR ligands, kinase inhibitors, ion channel modulators, enzymes and nuclear receptors (Lipinski CA et al., 2001).

\section{C) Virtual screening of ADMET properties analysis:}

The pharmacokinetic properties such as Absorption, Distribution, Metabolism, Excretion and Toxicity of the compounds were predicted using admetSAR database. In admetSAR is a web based query tools incorporating a molecular build-in interface enable the database to be queried by SMILES and structural similarity search (S.K. Balani et al., 2005).

\section{Analysis of PHB for Biomedical application}

\section{A) Designing of standard ligands}

The chemical structures of the selected ligands were drawn by using Chemsketch. Chemsketch is the powerful all-purpose chemical drawing and graphics package from ACD $\backslash$ Labs developed to help chemists quickly and easily draw molecules, reactions and schematic diagrams, calculate chemical properties, and design professional reports and presentations. ACD Chemsketch can convert SMILES notation to structure and vice versa. The drawn chemical structures were stored in PDB format.

\section{B) Preparation of PHB \& ligand conjugation}

PHB Ligand conjugation prepared by using defined chemical structure of PHB \& Ligand using Marvinsketch.

\section{3. virtual screening of PHB tagged Ligand}

\section{A) Virtual screening by Lipinski Rule of Five:}

Molecular descriptors and drug likeliness properties of compounds were analyzed using the Molinspiration server with based on Lipinski's Rules. Molinspiration server supports for calculation of important molecular properties such as LogP, polar surface area, number of hydrogen bond donors and acceptors, as well as prediction of bioactivity score for the most important drug targets GPCR ligands, kinase inhibitors, ion 
channel modulators, enzymes and nuclear receptors (Lipinski CA et al., 2001).

B) Virtual screening of ADMET properties analysis:

The pharmacokinetic properties such as Absorption, Distribution, Metabolism, Excretion and Toxicity of the compounds were predicted using admetSAR database. In admetSAR is a web based query tools incorporating a molecular build-in interface enable the database to be queried by SMILES and structural similarity search (S.K. Balani et al., 2005).

C) Molecular docking of PHB tagged ligands and energy calculation

The molecular interaction and binding studies of designed chemical ligands with all the four proteins were carried out by molecular docking by using Hex software. The efficiency of ligand was determined by energy calculation tabulated for respective ligand and protein. Hex is an interactive Molecular Graphics program for calculating and displaying feasible docking modes of pairs of protein and DNA molecules. Hex can also calculate Protein-Ligand docking, assuming the Ligand is rigid, and it can superpose pair of molecule using only knowledge of their 3D shapes. It uses Spherical Polar Fourier (SPF) correlation to accelerate the calculations and its one of the few docking programs which has built in graphics to view the result.

\section{RESULTS AND DISCUSSION}

\section{Insilico analysis of PHB}

\section{A) Thermal and mechanical properties:}

Matweb tool predicts mechanical \& thermal properties. Matweb tool supports for calculation of important properties Melting Temperature (Tm, ${ }^{\circ} \mathrm{C}$ ) , Tensile Strength (Mpa), Tensile modulus (GPa), Elongation at break (\%), Glass transition temperature $\left(\mathrm{Tg},{ }^{\circ} \mathrm{C}\right)$ as shown in Table 1 .
TABLE 1. Showing Mechanical and Thermal Properties of PHB

\begin{tabular}{|c|c|}
\hline Properties & PHB \\
\hline $\begin{array}{c}\text { Melting Temperature } \\
\left(\mathrm{Tm},{ }^{\circ} \mathrm{C}\right)\end{array}$ & 120 \\
\hline Tensile Strength (Mpa) & $40.0 \mathrm{Mpa}$ \\
\hline Tensile modulus (GPa) & $3.50 \mathrm{GPa}$ \\
\hline Elongation at break (\%) & 6 \\
\hline $\begin{array}{r}\text { Glass transition temperature } \\
\left(\mathrm{Tg},{ }^{\circ} \mathrm{C}\right)\end{array}$ & 4 \\
\hline
\end{tabular}

\section{B) Virtual screening by Lipinski Rule of Five:}

Molecular descriptors and drug likeliness properties of compounds were analyzed using the Molinspiration server with based on Lipinski's Rules as shown in Table 2. Molecule which satisfy the Lipinski's rule i.e. $\log \mathrm{P} \leq 5$, molecular weight $\leq 500$, number of hydrogen bond acceptors $\leq 10$, and number of hydrogen bond donors $\leq 5$ and number of rotatable bond $\leq 10$; were subjected for further analysis.

TABLE 2. Showing Predicted Important Molecular Properties

\begin{tabular}{|c|r|l|l|l|}
\hline Compoud & LogP & MW & Non & Nohnh \\
\hline $\begin{array}{c}{[\mathrm{PHB}]} \\
3\end{array}$ & 4.26 & 348.47 & 6 & 0 \\
\hline $\begin{array}{c}{[\mathrm{PHB}]} \\
4\end{array}$ & 5 & 464.63 & 8 & 0 \\
\hline $\begin{array}{c}\mathrm{PHB}] \\
5\end{array}$ & 6.57 & 580.79 & 10 & 0 \\
\hline
\end{tabular}

\section{C) ADMET analysis:}

The pharmacokinetic properties such as Absorption, Distribution, Metabolism, Excretion and Toxicity of 
the compounds were predicted using admetSAR database as shown in Table 3.

TABLE 3. Showing Predicted ADMET Properties

\section{Analysis of PHB for Biomedical application}

\begin{tabular}{|l|l|l|l|l|}
\hline $\begin{array}{l}\text { Compou } \\
\text { nd }\end{array}$ & $\begin{array}{l}\text { Brain } \\
\text { blood } \\
\text { barrier }\end{array}$ & $\begin{array}{l}\text { Human } \\
\text { intestinal } \\
\text { absortion }\end{array}$ & $\begin{array}{l}\text { Carcinog } \\
\text { enicity }\end{array}$ & $\begin{array}{l}\text { AMES } \\
\text { toxicity }\end{array}$ \\
\hline$[\mathrm{PHB}]_{3}$ & BBB+ & HIA+ & $\begin{array}{l}\text { No } \\
\text { Carcinog } \\
\text { enicity }\end{array}$ & $\begin{array}{l}\text { No } \\
\text { AMES } \\
\text { toxicity }\end{array}$ \\
\hline$[\mathrm{PHB}]_{4}$ & BBB+ & HIA+ & $\begin{array}{l}\text { No } \\
\text { Carcinog } \\
\text { enicity }\end{array}$ & $\begin{array}{l}\text { No } \\
\text { AMES } \\
\text { toxicity }\end{array}$ \\
\hline$[\mathrm{PHB}]_{5}$ & BBB+ & HIA+ & $\begin{array}{l}\text { No } \\
\text { Carcinog } \\
\text { enicity }\end{array}$ & $\begin{array}{l}\text { No } \\
\text { AMES } \\
\text { toxicity }\end{array}$ \\
\hline
\end{tabular}

\section{A) Designing of standard ligands}

The chemical structures of the selected ligands were drawn by using Chemsketch. Based on molecular properties and toxicity properties of ligand structure were built and represented in figure 1 respectively.

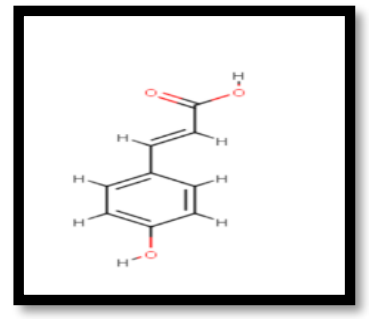

P-coumeric acid

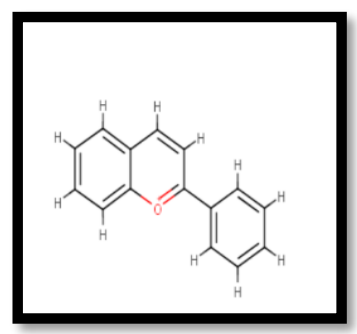

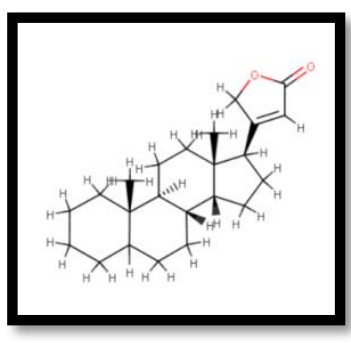

Cardenolide

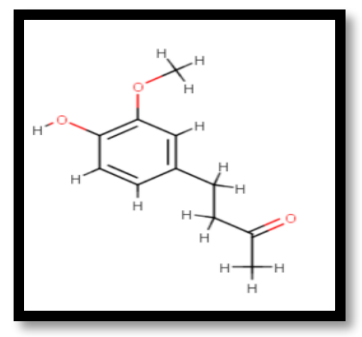

Zingerone

Figure1. Showing Structures of Standard Ligands

\section{B) Preparation of PHB \& ligand conjugation}

PHB Ligand conjugation prepared by using defined chemical structure of PHB \& Ligand using Marvinsketch. Conjugated PHB and Ligand structure represented in figure 2, 3, 4 and 5 respectively.
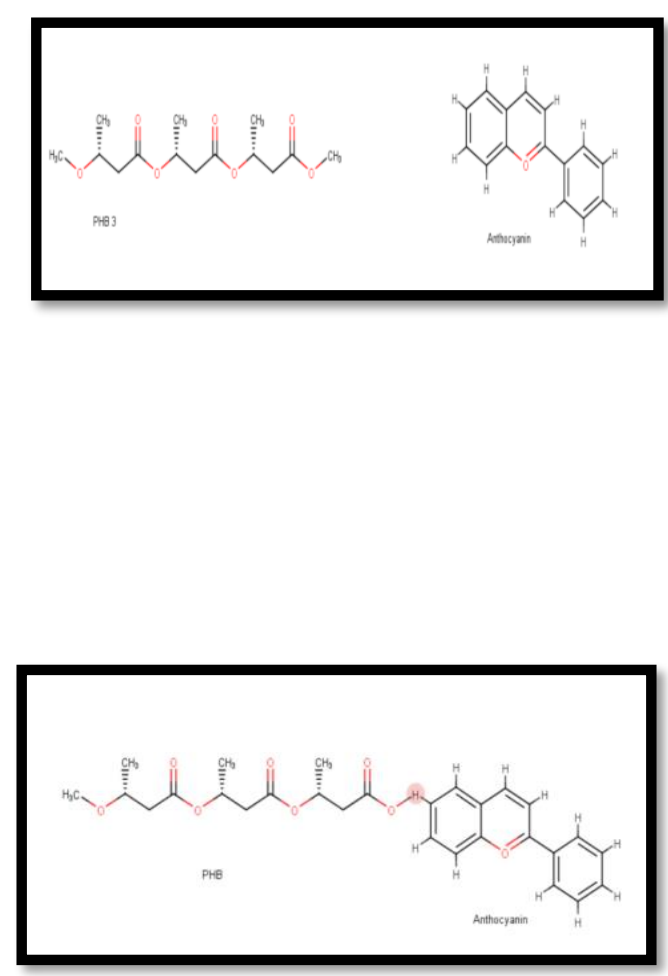

Figure 2. Showing Conjugated structure of PHBAnthocyanin 

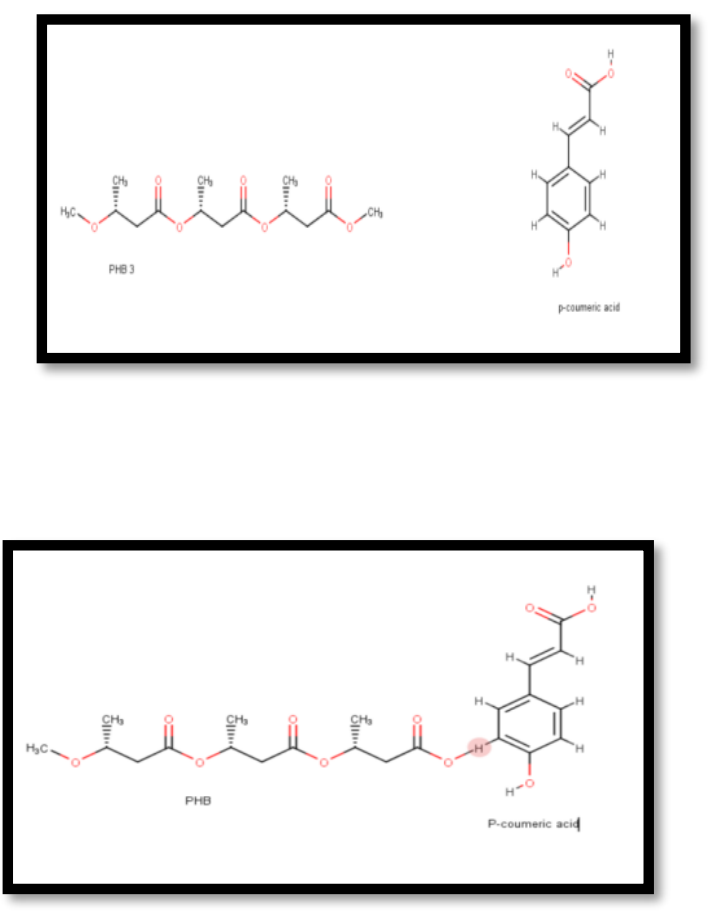

Figure 3. Showing Conjugated structure of PHB-Pcoumeric acid

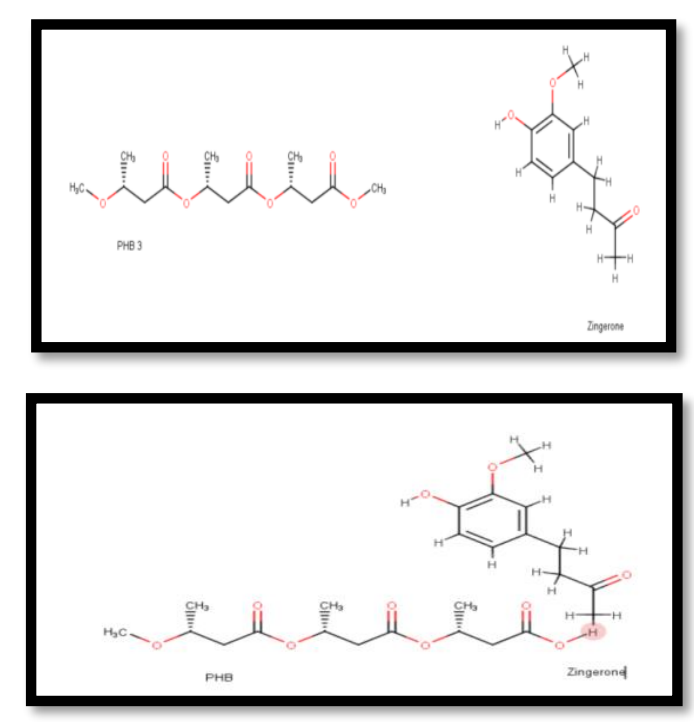

Figure 4. Showing Conjugated structure of PHBZingerone

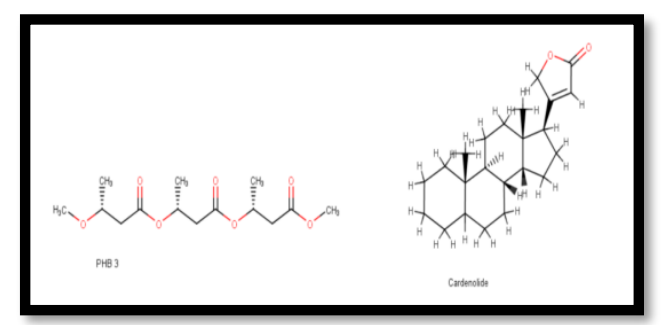

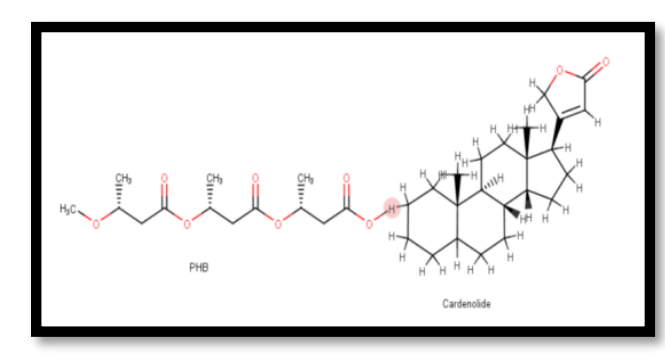

Figure 5. Showing Conjugated structure of PHBCardenolide

\section{Virtual screening of PHB tagged Ligand}

\section{A) Virtual screening by Lipinski Rule of Five:}

Molecular descriptors and drug likeliness properties of compounds were analyzed using the Molinspiration server with based on Lipinski's Rules as shown in Table 4. Molecule which satisfy the Lipinski's rule i.e. $\log \mathrm{P} \leq 5$, molecular weight $\leq 500$, number of hydrogen bond acceptors $\leq 10$, and number of hydrogen bond donors $\leq 5$ and number of rotatable bond $\leq 10$; were subjected for further analysis.

TABLE 4. Showing Predicted Important Molecular Properties

\begin{tabular}{|c|c|c|c|c|}
\hline Compound & LogP & MW & nON & Nohnh \\
\hline $\begin{array}{l}\text { PHB- } \\
\text { Anthocya } \\
\text { nin }\end{array}$ & 2.19 & 496.56 & 8 & 1 \\
\hline $\begin{array}{l}\text { PHB-p- } \\
\text { coumeric } \\
\text { acid }\end{array}$ & 2.53 & 453.46 & 10 & 3 \\
\hline $\begin{array}{l}\text { PHB- } \\
\text { Cardenoli } \\
\text { de }\end{array}$ & 4.89 & 631.83 & 9 & 1 \\
\hline $\begin{array}{l}\text { PHB- } \\
\text { Zingerone }\end{array}$ & 1.98 & 483.53 & 10 & 2 \\
\hline
\end{tabular}


TABLE 5. Showing Predicted ADMET Properties

\begin{tabular}{|l|l|l|l|l|}
\hline $\begin{array}{l}\text { Comp } \\
\text { ound }\end{array}$ & $\begin{array}{l}\text { Brain } \\
\text { blood } \\
\text { barrie } \\
\text { r }\end{array}$ & $\begin{array}{l}\text { Human } \\
\text { intestina } \\
\text { l } \\
\text { absortio } \\
\text { n }\end{array}$ & $\begin{array}{l}\text { Carcino } \\
\text { genicity }\end{array}$ & $\begin{array}{l}\text { AMES } \\
\text { toxicity }\end{array}$ \\
\hline $\begin{array}{l}\text { PHB- } \\
\text { Anthoc } \\
\text { yanin }\end{array}$ & BBB+ & HIA+ & $\begin{array}{l}\text { No } \\
\text { carcinog } \\
\text { enicity }\end{array}$ & $\begin{array}{l}\text { No AMES } \\
\text { toxicity }\end{array}$ \\
\hline $\begin{array}{l}\text { PHB- } \\
\text { P- } \\
\text { coumer } \\
\text { ic acid }\end{array}$ & BBB+ & HIA+ & $\begin{array}{l}\text { No } \\
\text { carcinog } \\
\text { enicity }\end{array}$ & $\begin{array}{l}\text { No AMES } \\
\text { toxicity }\end{array}$ \\
\hline $\begin{array}{l}\text { PHB- } \\
\text { Carden } \\
\text { olide }\end{array}$ & BBB+ & HIA+ & $\begin{array}{l}\text { No } \\
\text { carcinog } \\
\text { enicity }\end{array}$ & $\begin{array}{l}\text { No AMES } \\
\text { toxicity }\end{array}$ \\
\hline $\begin{array}{l}\text { PHB- } \\
\text { zingero } \\
\text { ne }\end{array}$ & BBB+ & HIA+ & $\begin{array}{l}\text { No } \\
\text { carcinog } \\
\text { enicity }\end{array}$ & $\begin{array}{l}\text { No AMES } \\
\text { toxicity }\end{array}$ \\
\hline
\end{tabular}

\section{B) Virtual screening of ADMET properties analysis:}

The pharmacokinetic properties such as Absorption, Distribution, Metabolism, Excretion and Toxicity of the compounds were predicted using admetSAR database as shown in Table 5.

\section{C) Molecular docking of PHB tagged ligands and Energy calculation}

The molecular interaction and binding studies of designed chemical ligands with all the four proteins were carried out by molecular docking by using Hex software. The efficiency of binding of each ligand to individual protein was determined by calculating binding energy scores as represented in table 6 . Docking between protein and ligand was shown in figure 6, 7, 8 and 9 respectively.

TABLE 6. Receptor-Ligand Binding Energy Scores

\begin{tabular}{|l|l|l|}
\hline Ligand & \multicolumn{1}{|c|}{ Receptor } & E total \\
\hline $\begin{array}{l}\text { PHB- } \\
\text { Anthocyanin }\end{array}$ & $\begin{array}{l}\text { Mammalian } \\
\text { sterile 20-like } \\
\text { Kinase-1(MST 1) }\end{array}$ & -328.95 \\
\hline $\begin{array}{l}\text { PHB-p- } \\
\text { coumeric acid }\end{array}$ & $\begin{array}{l}\text { NS2BNS3 } \\
\text { PROTEASE }\end{array}$ & -293.66 \\
\hline $\begin{array}{l}\text { PHB- } \\
\text { Cardenolide }\end{array}$ & $\begin{array}{l}\text { NS2BNS3 } \\
\text { PROTEASE }\end{array}$ & -358.92 \\
\hline PHB-Zingerone & $\begin{array}{l}\text { X linked } \\
\text { inhibitor of } \\
\text { apoptosis(1c9q) }\end{array}$ & -250.83 \\
\hline
\end{tabular}

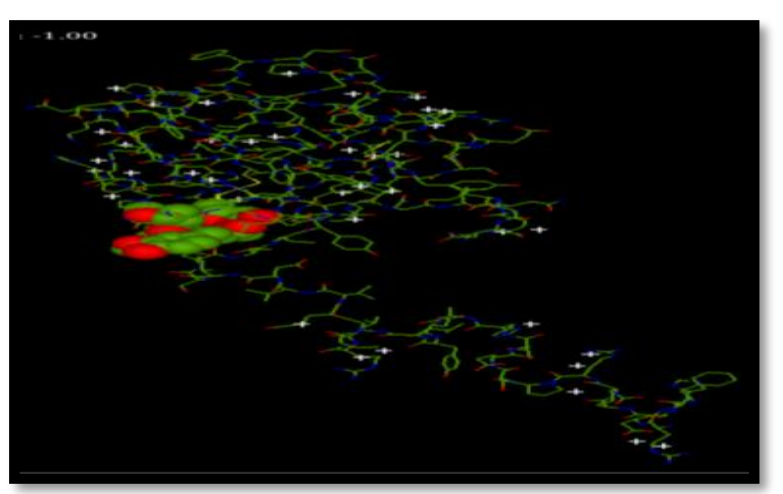

Figure 6. Showing receptor $X$ linked inhibitor of apoptosis (1c9q) and Ligand (PHB-Zingerone) docking.

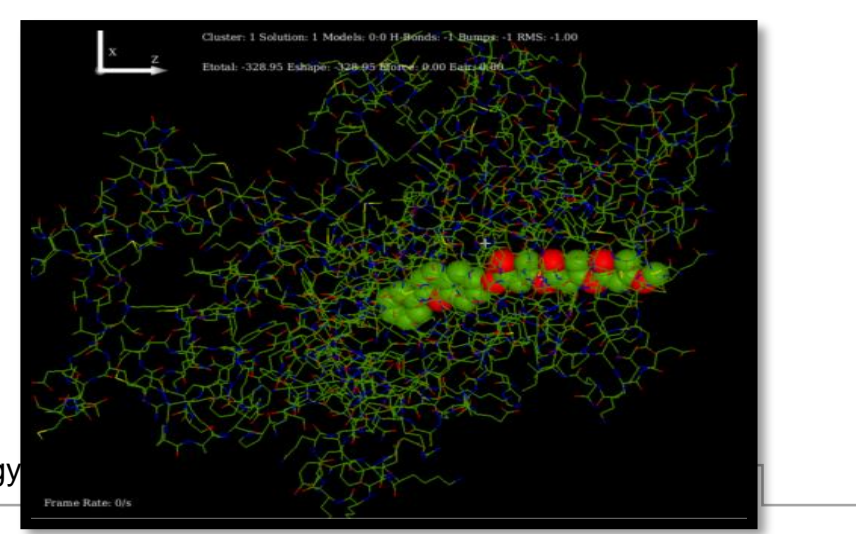


Figure7. Showing receptor Mammalian sterile 20-like Kinase-

1(MST1) and Ligand (PHB-Anthocyanin) docking.

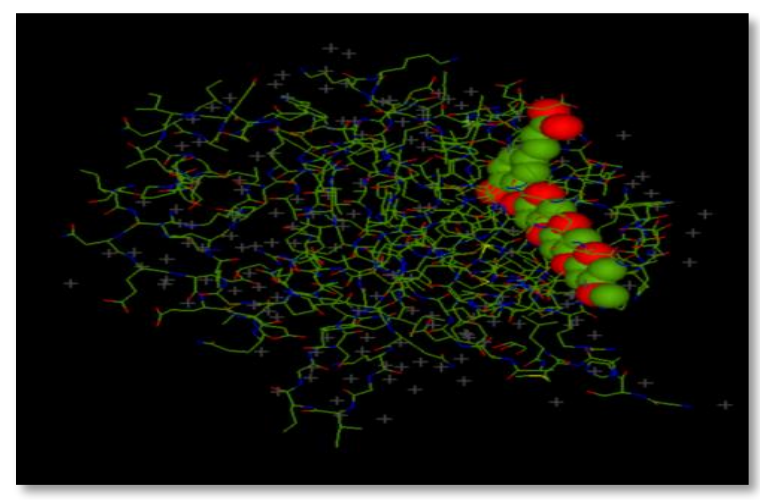

Figure8:Showing receptor NS2BNS3 PROTEASE and

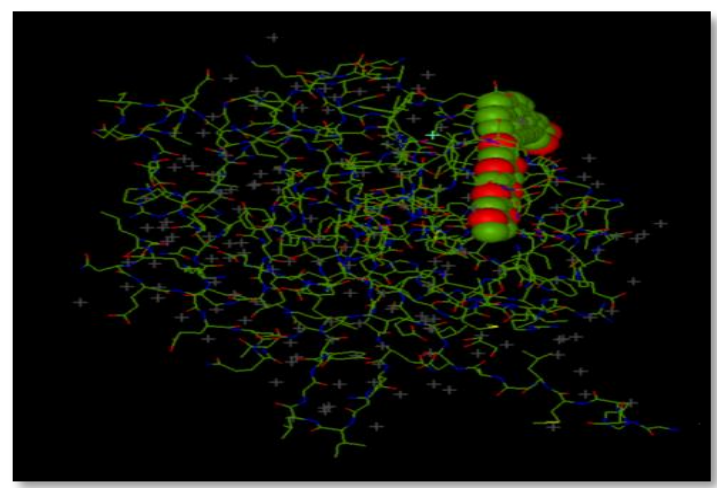

Figure9: Showing receptor NS2BNS3 PROTEASE and Ligand (PHB-Cardenolide) docking.

\section{CONCLUSION}

In-silico screening of PHB to understand Thermal and Mechanical properties. The biochemical application of
PHB as a drug delivery system was carried out by insilico analysis of its molecular properties, Toxicity and metabolism, further the efficiency of PHB as a drug delivery component was assessed by tagging with standard drug and molecular docking with respective target proteins. Currently the PHB type's polymer has been employed for medical application such as sutures, implants, urological stents, neutral- and cardiovascular- tissue engineering, facture fixation, treatment of narcolepsy and alcohol addiction, drug delivery vehicles, cell microencapsulation, support of hypophyseal cell, or as precursor of molecules with anti-rheumatic, analgesics radiopotentiator, chemopreventive, antihelminthic or anti-tumoral properties. Increased interest in the use of PHB for medical applications had arisen the response to the need for the field of drug delivery, where a much wider range of biodegradable and biocompatible polymers are being use as drug carriers. Because of their versatility and wide range of properties, biodegradable $\mathrm{PHBs}$ are being used as novel drug delivery systems. PHB-based drug carrier holds tremendous promise in the areas of cancer therapy and controlled delivery of drugs including steroids, vaccines, and other biological molecules. They can be formulated for targeted drug delivery to tumours or organs.

\section{REFERENCES}

[1]. Kalia VC, Chauhan A, Bhattacharyya G. Nat Biotechnol (2003); 21:845.

[2]. Reddy CSK, Ghai R, Kalia V. Bioresour Technol (2003); 87:137-46.

[3]. Boyandin AN, Prudnikova SV, Filipenko ML, Khrapov EA, Vasil'ev AD, Volova TG. (2012) Biodegradation of Polyhydroxyalkanoates by Soil Microbial Communities of Different Structures and Detection of PHA Degrading Microorganisms. Appl Biochem Microbiol; 
48(1):

35-44.

http://dx.doi.org/10.1134/S0003683812010024

[4]. Brigham CJ, Kurosawa K, Rha CK, Sinskey AJ. (2011)Bacterial carbon storage to value added products. J Microbial Biochem Technol; 83: S3002. http://dx.doi.org/10.4172/1948-5948.S3002 .

[5]. Mukai K, Doi Y, Sema Y, Tomita K. (1993)Substrate specificities in hydrolysis of polyhydroxyalkanoates by microbial esterases. Biotechnol Lett; 15(6): 601-4. http://dx.doi.org/10.1007/BF00138548 .

[6]. S. Y. Lee and H. N. Chang, (1995)“Production of poly (3-hydroxybutyric acid) by recombinant Escherichia coli strains: genetic and fermentation studies," Canadian Journal of Microbiology, vol. 41, no. 1, pp. 207-215.

[7]. C. Errico, C. Bartoli, F. Chiellini, and E. Chiellini,(2009)“Poly(hydroxyalkanoates)based polymeric nanoparticles for drug delivery," Journal of Biomedicine and Biotechnology, vol, Article ID 571702, 10 pages.

\section{Cite this article as :}

Vinod. P.S, Neha Guttikonda, Snehal. M. Mathe, M B Sulochana, "Insilico Analysis of PHB from Halophiles for potential Bio-medical applications", International Journal of Scientific Research in Science and Technology (IJSRST), Online ISSN : 2395-602X, Print ISSN : 2395-6011, Volume 6 Issue 3, pp. 211-218, MayJune 2019. Available at doi : https://doi.org/10.32628/IJSRST196338 Journal URL : http://ijsrst.com/IJSRST196338 